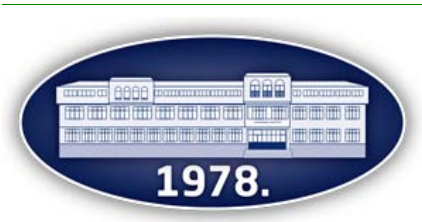

Publisher: Faculty of Agronomy Čačak

\title{
Variability in pomological traits of dog rose (Rosa canina L.) under the ecological conditions of the Republic of Croatia
}

\author{
Nikola Tomljenović1 ${ }^{1}$ Tomislav Jemrić2* ${ }^{*}$, Marko Vuković ${ }^{2}$ \\ ${ }^{1}$ Agriculture School Zagreb, Gjure Prejca 2, 10040 Zagreb, Croatia \\ 2University of Zagreb Faculty of Agriculture, Unit of Horticulture and Landscape Architecture, Department of Pomology, \\ Svetošimunska cesta 25, 10000 Zagreb, Croatia
}

*Corresponding author: tjemric@agr.hr

Received 4 December 2020; Accepted 28 April2021

\begin{abstract}
A B S T R A C T
Wild or dog rose (Rosa canina L.) is a successful colonizer of various habitats and different soil types and is widely distributed across the Republic of Croatia. In this research, in order to estimate pomological variability in native dog rose populations, four genotypes from four locations in different geographic areas of Croatia were selected and sampled. The genotypes selected were: genotype G1, originating from the continental part of Croatia (Pitomača); genotypes G2 and G3, originating from the Mediterranean part of Croatia (Kukurini and Posedarje, respectively); and genotype G4, originating from the upland part of Croatia (Gračac). Fruits were harvested at optimum harvest dates in 2010 and 2012. Genotype had a significant effect on each studied pomological trait (length, width, geometric mean diameter, sphericity, volume, surface, shape index, weight, flesh weight, flesh ratio and total dry matter content), while year significantly affected all parameters except sphericity and shape index. The highest values for most pomological traits in 2010 and 2012 were found in the G4 and G3 genotypes, respectively. This research highlighted the existence of high variability in pomological traits among dog rose populations in Croatia, which emphasizes the possibility of further breeding and cultivation.
\end{abstract}

Keywords: Rosa canina L., dog rose, wild rose, pomological traits, variability.

\section{И 3 В 0 Д}

Дивља ружа (Rosa canina L.) успешан је колонизатор различитих станишта и врста тла и раширена је у целој Републици Хрватској. Како би се утврдила помолошка варијабилност популација домаћих дивљих ружа, одабрана су и узоркована четири генотипа дивље руже са четири различита подручја у Републици Хрватској. Одабрани су следећи генотипови: генотип Г1, пореклом из континенталног дела Републике Хрватске (Питомача); генотипови Г2 и Г3, пореклом из медитеранског дела Републике Хрватске (Кукурини и Поседарје); и генотип Г4, пореклом из планинског дела Републике Хрватске (Грачац). Плодови су убрани у оптималној зрелости 2010. и 2012. године. Генотип је имао значајан утицај на све истраживане помолошке параметре (дужина, ширина, средњи геометријски пречник, сферичност, запремина, површина, индекс облика, тежина плода, маса меса, принос и укупан садржај суве материје). Година је имала значајан утицај на већину истражених параметара, са изузетком сферичности и индекса облика. Највише вредности за већину истражених помолошких параметара у 2010. години забележене су за генотип Г4, а 2012. за генотип Г3. Ово истраживање наглашава постојање велике варијабилности између популација дивљих ружа у Републици Хрватској, што даје могућност даље селекције и узгоја.

Кључне речи: Rosa canina L., дивља ружа, помолошки параметри, варијабилност.

\section{Introduction}

Wild or dog rose (Rosa canina L.), the most abundant species of the genus Rosa, is a successful colonizer of various habitats and different soil types and is widely distributed across the Republic of Croatia. In different localities it is known by various common names, like 'šipak', 'pasja drača', 'šipurak' etc. The genus Rosa includes 37 species in Croatia (Nikolić, 2018), 47 in Europe (Wrońska-Pilarek and Jagodziński, 2009) and 100-250 or even more worldwide (Rehder, 1940; Gudin, 2000; Jian et al., 2010; Popek, 1996; Wissemann, 2003; Smulders et al., 2011). These differences are the result of difficulties in identification due to heterogamous canina meiosis, variability inside the species, predominant matroclinal inheritance, polyploidy and interspecific hybridization (De Cock et al., 2008). Due to its valuable chemical composition (Vasić et al., 2020), the utilization of dog rose fruits has a long tradition (tea, jam, dessert soups, syrup, marmalade, jelly etc.), but it is rarely consumed raw. According to the macroscopic remains of the British flora, the fruits of different dog rose species were used as food in the late Neolithic Ages, Iron Ages, Old Ages and Middle Ages (Godwin 1975). In the Middle Ages, dog rose plants were used for medicinal purposes and 
almost all plant parts were utilized (fruit, seed, petal, leaf and root). Since the first half of the 19th century, they have been used as decoration and rootstocks for grafting cultivated ornamental varieties (De Vries, 2003; Werlemark and Nybom, 2010), as it was the case with other wild species (Hrotkó et al., 2008). Dog rose is also used for erosion prevention on infertile soils (Turkben et al., 2005).

In wild rose breeding, the greatest attention is paid to fruit quality, which is the main key to market expansion. However, other traits, such as the absence of prickles, processing potential, adaptability and resistance or tolerance to pests, are also important. Dog rose fruit contains 10 to 50 times more vitamin $C$ than orange fruit, and the highest amount of vitamin $\mathrm{C}$ among all studied species of the genus Rosa L. (Türkben et al., 2005). Dog rose fruits have better antioxidant properties than fruits from other fruit species well known for their good antioxidant potential, such as service tree, hawthorn, chokeberry, blackcurrant and blueberry (Mármol et al., 2017). Dog rose fruits contain more than 130 compounds (Cendrowski et al., 2012), such as fatty acids (Vasić et al., 2020).

Studies of some individual pomological traits (size, shape, fruit weight and quantity of vitamin C) of different populations of dog rose species in Romania indicate the existence of notable variations between genotypes in the same population (Ghiorghiță et al., 2012a). This emphasizes the importance of studying variability in dog rose genotypes from various populations in order to isolate the ones that stand out for their productivity and quality traits useful in breeding. As determined by Werlemark (2000), dog rose has a high level of variability between populations, but low intraspecies variability. Further studies of phenotypically divergent genotypes will be very useful since in Croatia Šindrak et al. (2012) reported notable differences in $R$. canina plants that grow in the same area, thus showing their potential for breeding purposes. Therefore, the goal of this research was to assist in the isolation of dog rose genotypes with desirable traits from their natural populations in order to create new varieties and hybrids suitable for cultivation.

\section{Materials and methods}

\subsection{Plant material}

To estimate pomological variability in native dog rose ( $R$. canina L.) populations, four genotypes from four different geographic areas of Croatia were selected and sampled. Genotypes were labeled G1 to G4 as follows: genotype G1, originating from the continental part of Croatia (Pitomača); genotypes G2 and G3, originating from the Mediterranean part of Croatia (Kukurini and Posedarje, respectively); and genotype G4, originating from the upland part of Croatia (Gračac) (Figure 1).

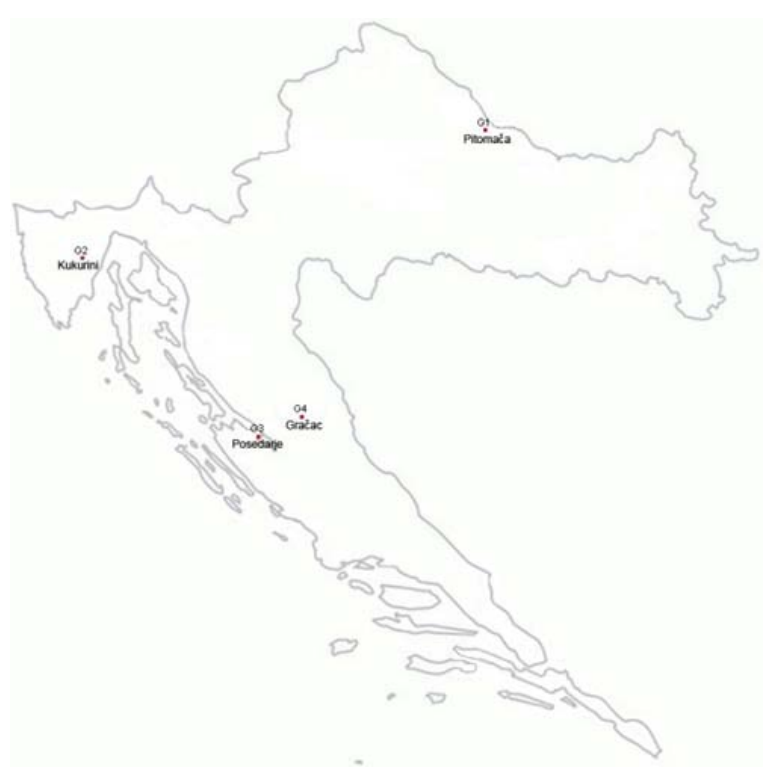

Figure 1. Geographic locations of analyzed dog rose genotypes with associated markings

\subsection{Botanical analyses}

Botanical analyses of selected genotypes were conducted at the Department of Environmental Biology, University of Sapienza, Rome by Professor E. Lattanzi. All four genotypes were affiliated to the species Rosa canina L.

\subsection{Pomological measurements}

Fruits were harvested at optimum harvest dates in 2010 and 2012. Afterwards, fruits were transferred to the Laboratory of the Department of Pomology, Unit of Horticulture and Landscape Architecture, Faculty of Agriculture, University of Zagreb, where measurements were conducted. The following pomological parameters were measured: fruit length $(\mathrm{mm})$, fruit width $(\mathrm{mm})$, geometric mean diameter ( $\mathrm{mm})$, fruit sphericity (\%), fruit volume $\left(\mathrm{mm}^{3}\right)$, fruit surface $\left(\mathrm{mm}^{2}\right)$, fruit weight $(\mathrm{g})$, fruit flesh weight $(\mathrm{g})$, fruit flesh ratio (\%), shape index, and total dry matter (\%). For each trait (except for total dry matter), 20 fruits of each genotype were analyzed per year. As regards total dry matter, 3 joint samples per year were analyzed (a total of 60 fruits in each year since 1 joint sample consisted of 20 fruits). 
Fruit length and fruit width ( $\mathrm{mm}$ ) were measured by a Prowin HMTY0006 digital caliper. Fruit weight (g) and fruit flesh weight (g) were measured by an OHAUS Adventurer AX2202 analytical balance. Fruit flesh ratio (\%) was calculated by equation: (fruit flesh weight / fruit weight) - 100). Sphericity, volume, geometric mean diameter (GMD) and fruit surface were calculated by the equations reported by Jain and Bal (1997) and McCabe et al. (1986) according to Demir and Kalyoncu (2003). Samples were dried by a Binder ED115 dryer, and analysis of total dry matter content was conducted according to Ghiorghita et al. (2012a) and Güneş (2010).

\subsection{Statistical analysis}

Data were statistically analyzed using SAS statistical software ver. 9.4 (SAS Institute, NC) using ANOVA and Tukey's HSD test $(P \leq 0.05)$.

\section{Results}

According to the ANOVA table (Table 1), year significantly affected all studied pomological traits $(P \leq$ 0.001 ) with the exception of sphericity and shape index. Genotype had a significant effect on each studied pomological trait $(P \leq 0.001)$. Interaction between year and genotype had a significant effect on all studied pomological traits $(\mathrm{P} \leq 0.001)$ with the exception of sphericity, shape index and fruit flesh ratio. Due to the significant effect of year on the majority of studied pomological traits, the results were additionally analyzed separately for each year (Tables 2 and 3). In both years, genotype significantly affected all pomological traits $(P \leq 0.001)$.

Table 2 and 3 present the pomological trait values of studied dog rose genotypes. In 2010 and 2012, genotype G1 had significantly higher fruit length than genotypes G2 and G4. In 2010, genotype G2 had the significantly smallest fruit length. In 2010, genotype G4 had the significantly highest fruit width and was followed by genotype G3. No significant difference was recorded between genotypes G2 and G1. In 2012, genotypes G4 and G3 had significantly higher fruit width than genotypes G1 and G2. In 2010, genotypes G3 and G4 had the significantly highest geometric mean diameter, and were followed by genotype G1, while genotype G2 had the significantly lowest geometric mean diameter. In 2012, genotype G3 had a significantly higher geometric mean diameter than genotypes G1 and G2, while no significant difference was recorded between the other genotypes. In 2010 and 2012, the significantly highest fruit sphericity value was found in genotype G4, followed by genotypes G2 and G3, while the significantly lowest fruit sphericity value was measured in genotype G1. In 2010, fruit volume was significantly highest in genotype G4, followed by genotype G3, and significantly lowest in genotypes G1 and G2. In 2012, genotypes G3 and G4 had significantly higher fruit volume than genotypes G1 and G2. In 2010, the significantly highest fruit surface value was measured in genotypes G3 and G4, followed by genotype G1, and the lowest in genotype G2. In 2012, genotype G3 had a significantly higher fruit surface value than genotypes G1 and G2, while in other cases no significant difference was recorded. In 2010 and 2012, the significantly highest shape index value was found in genotype G1, and the significantly lowest in genotype G4. In 2010 and 2012, genotypes G3 and G4 had significantly higher fruit weight than genotypes G1 and G2. In 2010, genotypes G3 and G4 had the significantly highest flesh weight, while genotype G2 had the lowest. In 2012, genotype G3 had significantly higher flesh weight than genotypes G1 and G2 as well as genotype G4 than genotype G2. In 2010, genotype G1 had the significantly highest fruit flesh ratio, while genotype G3 had a higher value than genotype G2. In 2012, genotype G1 had the significantly highest fruit flesh ratio, while genotype G2 had the lowest. In 2010, the significantly highest content of fruit total dry matter was measured in genotype G3, followed by genotype G2, while the significantly lowest content of fruit total dry matter was recorded in genotypes G1 and G4. In 2012, the content of fruit total dry matter was significantly highest in genotypes G2 and G3, followed by genotype G4, while the significantly lowest content of fruit total dry matter was found in genotype G1. 
Table 1.

ANOVA table of pomological traits of dog rose genotypes

\begin{tabular}{|c|c|c|c|c|c|c|c|c|c|c|c|}
\hline Source & Length & Width & GMD & Sphericity & Volume & Surface & Shape index & Fruit weight & $\begin{array}{c}\text { Flesh } \\
\text { weight }\end{array}$ & $\begin{array}{c}\text { Fruit flesh } \\
\text { ratio }\end{array}$ & $\begin{array}{c}\text { Total dry } \\
\text { matter }\end{array}$ \\
\hline Year $(\mathrm{Y})$ & $<0.0001^{* * *}$ & $<0.0001^{* * *}$ & $<0.0001^{* * *}$ & 0.1043 n.s. & $<0.0001^{* * *}$ & $<0.0001^{* * *}$ & 0.2313 n.s. & $<0.0001^{* * *}$ & $<0.0001^{* * *}$ & $<0.0001^{* * *}$ & $<0.0001^{* * *}$ \\
\hline Genotype (G) & $<0.0001^{* * *}$ & $<0.0001^{* * *}$ & $<0.0001^{* * *}$ & $<0.0001^{* * *}$ & $<0.0001^{* * *}$ & $<0.0001^{* * *}$ & $<0.0001^{* * *}$ & $<0.0001^{* * *}$ & $<0.0001^{* * *}$ & $<0.0001^{* * *}$ & $<0.0001^{* * *}$ \\
\hline Yx G & $0.0009 * * *$ & $<0.0001^{* * *}$ & $<0.0001^{* * *}$ & 0.2059 n.s. & $<0.0001^{* * *}$ & $<0.0001^{* * *}$ & 0.3017 n.s. & $<0.0001^{* * *}$ & $<0.0001^{* * *}$ & 0.3133 n.s. & $<0.0001^{* * *}$ \\
\hline \multicolumn{12}{|c|}{ Year 2010} \\
\hline Genotype & $<0.0001^{* * *}$ & $<0.0001^{* * *}$ & $<0.0001^{* * *}$ & $<0.0001^{* * *}$ & $<0.0001^{* * *}$ & $<0.0001^{* * *}$ & $<0.0001^{* * *}$ & $<0.0001^{* * *}$ & $<0.0001^{* * *}$ & $<0.0001^{* * *}$ & $<0.0001^{* * *}$ \\
\hline \multicolumn{12}{|c|}{ Year 2012} \\
\hline Genotype & $<0.0001^{* * *}$ & $<0.0001^{* * *}$ & $0.0008^{* * *}$ & $<0.0001^{* * *}$ & $<0.0001^{* * *}$ & $0.0007^{* * *}$ & $<0.0001^{* * *}$ & $<0.0001^{* * *}$ & $<0.0001^{* * *}$ & $<0.0001^{* * *}$ & $<0.0001^{* * *}$ \\
\hline
\end{tabular}

Table 2.

Length, width, geometric mean diameter (GMD), sphericity, volume, surface and shape index of fruits of dog rose genotypes (mean and standard deviation)

\begin{tabular}{|c|c|c|c|c|c|c|c|}
\hline Genotype & Length (mm) & Width (mm) & GMD (mm) & Sphericity (\%) & Volume $\left(\mathrm{mm}^{3}\right)$ & Surface $\left(\mathrm{mm}^{2}\right)$ & Shape index \\
\hline \multicolumn{8}{|c|}{ Year 2010} \\
\hline G1 & $23.30 \pm 3.12 \mathrm{a}$ & $11.36 \pm 0.76 \mathrm{c}$ & $14.41 \pm 1.14 \mathrm{~b}$ & $0.62 \pm 0.05 \mathrm{c}$ & $406.83 \pm 53.59 \mathrm{c}$ & $656.35 \pm 102.98 \mathrm{~b}$ & $2.05 \pm 0.23 \mathrm{a}$ \\
\hline G2 & $17.94 \pm 1.58 \mathrm{c}$ & $11.58 \pm 0.78 \mathrm{c}$ & $13.38 \pm 0.79 c$ & $0.75 \pm 0.05 b$ & $422.75 \pm 56.67 c$ & $564.57 \pm 66.92 c$ & $1.55 \pm 0.15 b$ \\
\hline G3 & $21.93 \pm 1.49 \mathrm{ab}$ & $14.04 \pm 1.19 \mathrm{~b}$ & $16.28 \pm 1.20 \mathrm{a}$ & $0.74 \pm 0.03 b$ & $623.32 \pm 100.91 \mathrm{~b}$ & $837.04 \pm 119.73 \mathrm{a}$ & $1.84 \pm 1.57 \mathrm{~b}$ \\
\hline G4 & $20.47 \pm 1.48 \mathrm{~b}$ & $15.17 \pm 0.70 \mathrm{a}$ & $16.76 \pm 0.87 \mathrm{a}$ & $0.82 \pm 0.03 \mathrm{a}$ & $724.11 \pm 65.95 \mathrm{a}$ & $884.38 \pm 89.53 \quad \mathrm{a}$ & $1.35 \pm 0.06 \mathrm{c}$ \\
\hline \multicolumn{8}{|c|}{ Year 2012} \\
\hline G1 & $21.75 \pm 3.78 \mathrm{a}$ & $11.19 \pm 0.67 \mathrm{~b}$ & $13.92 \pm 1.09 \mathrm{~b}$ & $0.65 \pm 0.07 c$ & $394.72 \pm 46.08 \mathrm{~b}$ & $612.72 \pm 96.77 \quad b$ & $2.47 \pm 1.94 \mathrm{a}$ \\
\hline G2 & $18.39 \pm 1.11 b c$ & $11.56 \pm 0.89 b$ & $13.49 \pm 0.78 \mathrm{~b}$ & $0.73 \pm 0.04 \mathrm{~b}$ & $422.46 \pm 68.72 \mathrm{~b}$ & $573.21 \pm 68.12 \mathrm{~b}$ & $1.60 \pm 0.13 b$ \\
\hline G3 & $19.97 \pm 1.90 \mathrm{ab}$ & $12.95 \pm 1.11 \mathrm{a}$ & $14.93 \pm 0.84 \mathrm{a}$ & $0.75 \pm 0.07 \mathrm{~b}$ & $530.90 \pm 90.56 a$ & $702.33 \pm 78.93 a$ & $1.56 \pm 0.23 b$ \\
\hline G4 & $16.83 \pm 1.85 \mathrm{c}$ & $13.12 \pm 1.45 \mathrm{a}$ & $14.25 \pm 1.50 \mathrm{ab}$ & $0.85 \pm 0.04 \mathrm{a}$ & $547.3 \pm 116.61 \mathrm{a}$ & $644.81 \pm 131.65 \mathrm{ab}$ & $1.29 \pm 0.09 \mathrm{c}$ \\
\hline
\end{tabular}

Note: means followed by the same letter with the same year are not significant according to Tukey's HSD test at the $P \leq 0.05$ significance leve

Table 3.

Fruit weight, flesh weight, fruit flesh ratio and total dry matter of fruits of dog rose genotypes (mean and standard deviation)

\begin{tabular}{|c|c|c|c|c|}
\hline Genotype & Fruit weight (g) & Flesh weight (g) & Fruit flesh ratio (\%) & Total dry matter content (\%) \\
\hline \multicolumn{5}{|c|}{ Year 2010} \\
\hline G1 & $1.46 \pm 0.32 \mathrm{~b}$ & $1.00 \pm 0.23 \mathrm{~b}$ & $68.38 \pm 3.15 \mathrm{a}$ & $31.11 \pm 0.76 \mathrm{c}$ \\
\hline G2 & $1.28 \pm 0.21 \mathrm{~b}$ & $0.77 \pm 0.12 \mathrm{c}$ & $60.46 \pm 3.07 \mathrm{c}$ & $33.79 \pm 0.58 b$ \\
\hline G3 & $2.27 \pm 0.47 \mathrm{a}$ & $1.44 \pm 0.31 \mathrm{a}$ & $63.31 \pm 2.98 b$ & $36.83 \pm 0.18 \mathrm{a}$ \\
\hline G4 & $2.38 \pm 0.34 \mathrm{a}$ & $1.49 \pm 0.21 \mathrm{a}$ & $62.58 \pm 2.21 \mathrm{bc}$ & $30.37 \pm 1.28 \mathrm{c}$ \\
\hline \multicolumn{5}{|c|}{ Year 2012} \\
\hline G1 & $1.33 \pm 0.29 \mathrm{~b}$ & $0.89 \pm 0.20 \mathrm{bc}$ & $66.80 \pm 6.20 \mathrm{a}$ & $23.24 \pm 0.61 \mathrm{c}$ \\
\hline G2 & $1.40 \pm 0.26 \mathrm{~b}$ & $0.78 \pm 0.13 \mathrm{c}$ & $55.52 \pm 3.18 \mathrm{c}$ & $34.67 \pm 0.55 \mathrm{a}$ \\
\hline G3 & $1.82 \pm 0.31 \mathrm{a}$ & $1.09 \pm 0.15 \mathrm{a}$ & $60.38 \pm 6.09 \mathrm{~b}$ & $33.72 \pm 1.82 \mathrm{a}$ \\
\hline G4 & $1.72 \pm 0.47 \mathrm{a}$ & $1.03 \pm 0.27 \mathrm{ab}$ & $60.09 \pm 3.92 \mathrm{~b}$ & $28.84 \pm 1.40 \mathrm{~b}$ \\
\hline
\end{tabular}

Note: means followed by the same letter with the same year are not significant according to Tukey's HSD test at the $P \leq 0.05$ significance level 


\section{Discussion}

The results obtained in this study confirm the existence of significant variability between dog rose populations in the Republic of Croatia. The genus Rosa is marked by huge phenotypic plasticity, which is caused by high phenotypic, genotypic and ecological variability due to different evolution processes such as hybridization and introgression (Ben Cheikh-Affene et al., 2015). For the majority of studied traits, the highest values in 2010 and 2012 were obtained by genotype G4 and G3, respectively. The significant effect of year on the majority of studied traits was probably due to less favorable ecological conditions in 2012, when the average values of most traits were reduced in comparison to 2010. Likewise, Uggla et al. (2003) in three-year research of Rosa species reported that, in one year, fruit weight values were reduced (except for $R$. villosa) as a result of a smaller amount of precipitation and difference in its distribution during fruit ripening. However, in this study, the exception was genotype G2, which, for the majority of fruit traits (length, geometric mean diameter, surface, shape index, fruit weight, flesh weight and total dry matter), had higher values in the less favorable year 2012 .

Fruit length is a highly variable trait (Soare et al., 2015). In this study, average fruit length values in 2010 varied from $17.94 \pm 1.58 \mathrm{~mm}(\mathrm{G} 2)$ to $23.30 \pm 3.12 \mathrm{~mm}$ (G1) and in 2012 they were somewhat reduced (ranging from $16.83 \pm 1.85 \mathrm{~mm}$ for G4 to $21.75 \pm 3.78$ $\mathrm{mm}$ for G1), but showed visible variability. In Van region (Turkey), the fruit length values of $R$. canina species ranged from $23.54 \mathrm{~mm}$ to $33.83 \mathrm{~mm}$ (Celik et al., 2009). Also in Turkey, the average fruit length values of wild dog rose populations ranged from 17.29 to $19.68 \mathrm{~mm}$ (Demir and Özcan, 2001). In Romania, minimal and maximal values for dog rose fruit length were $11.40 \mathrm{~mm}$ and $30.90 \mathrm{~mm}$, respectively (Rosu et al., 2011). In Croatia, the fruit length values of dog rose seedlings varied from 20.40 to $25.30 \mathrm{~mm}$ (Šindrak et al., 2012). Results in this study are within the range of values obtained in other studies.

In both experimental years, the average fruit width values were highest in genotype G4 $(15.17 \pm 0.70 \mathrm{~mm}$ and $13.12 \pm 1.45 \mathrm{~mm}$ for 2010 and 2012, respectively), and lowest in genotype G1 (11.36 $\pm 0.76 \mathrm{~mm}$ and 11.19 $\pm 0.67 \mathrm{~mm}$ for 2010 and 2012, respectively), with a tendency to reduce in 2012. In Van region (Turkey), Demir and Özcan (2001) reported that fruit width values in dog rose wild populations ranged from 11.16 $\mathrm{mm}$ to $13.20 \mathrm{~mm}$. The average fruit width of Rosa spp. selections from the Erzurum province of Turkey obtained by Ercișli and Eşitken (2004) varied from $15.04 \mathrm{~mm}$ to $19.69 \mathrm{~mm}$. Results in this study are within the range of values obtained in other studies. All this indicates a significant variation in dog rose fruit width. These traits are of huge agronomic importance since fruit length and fruit width have an effect on fruit weight.

The average geometric mean diameter showed a significant variation in both years (in 2010 it ranged from $13.38 \pm 0.79 \mathrm{~mm}$ for G2 to $16.76 \pm 0.87 \mathrm{~mm}$ for G4), but in 2012 variability was reduced, probably due to less favorable ecological conditions (in 2012 the range was from $13.49 \pm 0.78 \mathrm{~mm}$ for G2 to $14.93 \pm 0.84$ $\mathrm{mm}$ for G3). Following the same pattern, sphericity also showed significant variability in both years. In both years, the highest sphericity values (more rounded fruits) were obtained from fruits of genotype G4 (0.82 \pm 0.03 and $0.85 \pm 0.04$ for 2010 and 2012, respectively), while smaller sphericity values and somewhat more elongated fruits were obtained from fruits of genotype G1 $(0.62 \pm 0.05$ and $0.65 \pm 0.07$ for 2010 and 2012, respectively). In both years, the highest average fruit volume was measured in genotype G4 (724.11 \pm 65.95 $\mathrm{mm}^{3}$ and $547.30 \pm 116.61 \mathrm{~mm}^{3}$ for 2010 and 2012, respectively) and the smallest in G1 (406.83 \pm 53.59 $\mathrm{mm}^{3}$ and $394.72 \pm 46.08 \mathrm{~mm}^{3}$ for 2010 and 2012, respectively). In 2012, the values were again lower, probably due to less favorable ecological conditions, as mentioned before. In 2010, the highest average fruit surface value was obtained by genotype G4 (884.38 \pm $89.53 \mathrm{~mm}^{2}$ ) and in 2012 by genotype G3 (702.33 \pm $78.93 \mathrm{~mm}^{2}$ ). The smallest average fruit surface in both years was measured in genotype G2 (564.57 \pm 66.92 $\mathrm{mm}^{2}$ and $573.21 \pm 68.12 \mathrm{~mm}^{2}$ for 2010 and 2012, respectively).

The highest value of fruit shape index in both years was recorded for genotype G1 $(2.05 \pm 0.23$ and $2.47 \pm$ 1.94) and the lowest for G4 (1.35 \pm 0.06 and $1.29 \pm$ 0.09). In Turkey, the range of values for fruit shape index was 1.11-2.05 (the value for dog rose: 1.63) in six Rosa species from Lake Van Basin, Eastern Anatolia Region (Dogan and Kazankaya, 2006), 1.32-2.41 in Rosa spp. genotypes from Hakkari region (Ekincialp and Kazankaya, 2012), and 1.23-1.81 in Rosa spp. genotypes from Bolu Province (Ersoy and Özen, 2016). In Hungary, fruit shape index varied between 1.18 and 2.14 (for dog rose it was 1.82) (Kovács et al., 2000). In Romania, the fruit shape index of dog rose genotypes varied between 1.16 and 1.72 (Ghiorghiţă et al., 2012b). In Croatia, significantly different values of fruit shape index between eight dog rose seedlings varied between 1.48 and 1.86 (Šindrak et al., 2012). Results in this study are within the range of values obtained in most other published studies.

In 2010, the highest average fruit weight was obtained by genotype G4 ( $2.38 \pm 0.34 \mathrm{~g})$, while in 2012 by G3 $(1.82 \pm 0.31 \mathrm{~g})$. The smallest average fruit weight in 2010 was measured for genotype G2 $(1.28 \pm 0.21 \mathrm{~g})$ while in 2012 for G1 (1.33 $\pm 0.29 \mathrm{~g})$. In Turkey, the average values of 1000 measured dog rose fruits were between 1.00 and $1.59 \mathrm{~g}$ (Demir and Özcan, 2001). Also in Turkey (Van region), Celik et al. (2009) reported a significant variation in the fruit weight of different dog rose genotypes, which ranged from 2.6 to $4.95 \mathrm{~g}$. In additional research of superior genotypes, Celik et al. (2015) obtained values that varied from 2.43 to $4.88 \mathrm{~g}$. Ersoy and Özen (2016) reported that the average fruit weight of Rosa spp. genotypes from Turkey varied from 1.4 to $2.77 \mathrm{~g}$. In Romania, the range of values for average fruit biomass was 1.37-2.88 g for local dog rose populations (Ghiorghiță et al., 2012b), 1.06-2.74 g (Soare et al., 2015), and 2.19-3.72 $\mathrm{g}$ for three dog rose biotypes in three-year research (Ancu et al., 2012). In Tunisia, the average fruit weight varied between 2.99 and $4.34 \mathrm{~g}$ in local dog rose genotypes (Günes et al., 2016), and it was $1.00 \mathrm{~g}$ for $\mathrm{dog}$ rose and between 0.9 and $1.9 \mathrm{~g}$ for six Rosa spp. genotypes (Ben CheikhAffene et al., 2015). In Croatia, the average fruit weight of eight dog rose seedlings varied from 1.88 to $2.69 \mathrm{~g}$ (Šindrak et al., 2012). Results in this study are within the range of values obtained in other studies.

The highest average flesh weight in 2010 was recorded in genotype G4 $(1.49 \pm 0.21 \mathrm{~g})$, and in 2012 in G3 (1.09 \pm 0.15 g). In 2010 and 2012, the smallest flesh 
weight was obtained by G2 $0.77 \pm 0.12 \mathrm{~g}$ and $0.78 \pm$ $0.13 \mathrm{~g}$, respectively). In Tunisia, Ben Cheikh-Affene et al. (2015) analyzed the average flesh weight of four Rosa species and reported that it ranged from $0.69 \mathrm{~g}$ to $1.20 \mathrm{~g}$, while the flesh weight of dog rose was $0.77 \mathrm{~g}$. In Croatia, Šindrak et al. (2012) reported a significant difference in flesh weight among eight dog rose seedlings, and it varied from $1.31 \mathrm{~g}$ to $1.94 \mathrm{~g}$. Results in this study are within the range of values obtained in other studies.

The highest fruit flesh ratio in both years was found in genotype G1 $(68.38 \pm 3.15 \%$ and $66.80 \pm$ $6.20 \%$ for 2010 and 2012, respectively), and the smallest average in genotype G2 $(60.46 \pm 3.07 \%$ and $55.52 \pm 3.18 \%$ for 2010 and 2012, respectively). Fruit flesh ratio is an economically important trait since fruits are mainly used for processing (Güneș, 2010). In Turkey, the fruit flesh ratio values of Rosa species ranged from 59.33 to $76.69 \%$ (Ekincialp and Kazankaya, 2012), 63.11 to $71.13 \%$ (Ercişli and Eșitken, 2004), 64.92 to $82.83 \%$ (Ersoy and Özen 2016 ), and from 66.00 to $80.20 \%$ (for dog rose 77.90\%) (Güneş, 2010). Also in Turkey (Van region), Celik et al. (2009) reported that fruit flesh ratio in selected dog rose genotypes varied from 66.42 to $86.67 \%$. In a similar study, Celik et al. (2015) found lower values for fruit flesh ratio, which varied from 49.10 to $76.20 \%$. In Hungary, the fruit flesh ratio of Rosa species varied from 46.07 to $69.24 \%$ (for dog rose 62.66 \%) (Kovács et al., 2000). In four Rosa species (six accessions) from Tunisia, fruit flesh ratio varied from $63.60 \%$ (R. pomifera) to $73.7 \%$ (R. canina) (Ben CheikhAffene et al., 2015). In Croatia, the fruit flesh ratio of eight dog rose seedlings varied from $65.40 \%$ to $74.70 \%$ (Šindrak et al., 2012).

A study conducted by Uggla et al. (2003) indicated a highly significant positive correlation between fruit weight and the percentage of fruit flesh, and a moderate negative correlation between fruit weight and the percentage of dry matter. In 2010, the highest content of fruit total dry matter was recorded for genotype G3 $(36.83 \pm 0.18 \%)$ and the smallest average for G4 $(30.37 \pm 1.28 \%)$. In 2012 , the highest average content of fruit total dry matter was measured in genotype G2 $(34.67 \pm 0.55 \%)$ and the smallest in G1 $(23.24 \pm 0.61 \%)$. Celik et al. (2015) reported a high total fruit dry matter content of Rosa spp. from Turkey (region Van), which varied from 45.70 to $53.26 \%$. Also in Turkey, Demir and Özcan (2001) reported much lower values, which ranged from 20.50 to $23.47 \%$. The average values of fruit total dry matter of Rosa spp. selection from Erzurum province of Turkey ranged from 34.82 to $40.15 \%$ (Ercişli and Eşitken 2004), and from 33.85 to $40.35 \%$ (for dog rose $38.00 \%$ ) (Ercişli, 2007). In East Anatolia (Turkey), the fruit total dry matter of Rosa species varied from 34.34 to $66.70 \%$ (for dog rose 49.72\%) (Dogan and Kazankaya, 2006). The fruit total dry matter of Rosa species from Turkey ranged from 43.63 to $59.39 \%$ (Ekincialp and Kazankaya, 2012) and from 32.44 to $56.94 \%$ (Ersoy and Özen, 2016). In Romania, the average fruit total dry matter values of dog rose fruit ranged from 27.53 to 49.90\% (Rosu et al., 2011). In Croatia, the average fruit total dry matter values of eight dog rose seedlings varied from 22.90 to $28.60 \%$ (Šindrak et al., 2012). The majority of studies, especially Turkish, reported much higher values of total dry matter, which can be contributed to the effect of ecological and growing conditions as well as to fruit size and genetic potential.

\section{Conclusion}

This two-year study of dog rose pomological traits included four genotypes in three geographically and ecologically distinct regions. The analysis of pomological properties determined variability in studied dog rose genotypes as a result of the influence of ecological and hereditary factors. The highest values for most pomologically important traits in 2010 were obtained in genotype G4, while in 2012 in genotype G3. Hence this research highlighted the existence of high variability in pomological traits among dog rose populations in Croatia, which emphasizes the possibility of further breeding.

\section{Acknowledgment}

Special appreciation should be given to Professor E. Lattanzi from the Department of Environmental Biology, University of Sapienza, Rome for her valuable contribution to this research regarding the botanical determination of the studied Rosa canina L. genotypes.

\section{Declaration of competing interest}

The authors declare no conflict of interest.

\section{References}

Ancu, I., Mladin, G., Nuta, A., Sturzeanu, M., Ancu, S., Butac, M., Militaru, M. (2012). The study of native small fruits biotypes. Fruit growing research, 28.

Ben Cheikh-Affene, Z. B., Haouala, F., Harzallah-Skhiri, F. (2015). Morphometric variation and taxonomic identification of thirteen wild rose populations from Tunisia. Acta Botanica Croatica, 74(1), 1-17.

Celik, F., Kazankaya, A., Dogan, A., Gundogdu, M., Cangi, R. (2015). Some pomological and biochemical properties of rose hip (Rosa spp.) germplasm. Acta Horticulturae, 1089, 287-292.

Celik, F., Kazankaya, A., Ercisli S. (2009). Fruit characteristics of some selected promising rose hip (Rosa spp.) genotypes from Van region of Turkey. African Journal of Agricultural Research, 4(3), 236-240.

Cendrowski, A., Kalisz, S., Mitek, M. (2012). Właściwości i zastosowanie owoców róży w przetwórstwie spożywczym. Żywność. Nauka. Technologia. Jakość, 4(83), 24-31.

De Cock, K., Mijnsbrugge, K.V., Breyne, P., Van Bockstaele, E., Van Slycken, J. (2008). Morphological and AFLP-based differentiation within the taxonomical complex section Caninae (subgenus Rosa). Annals of Botany, 102, 685697.

De Vries, D. (2003). Rootstock breeding. In Roberts A.V., Debener T., Gudin S. (eds.), Encyclopedia of rose science, Elsevier Academic Press, Oxford, 639-645 pp.

Demir, F., Kalyoncu I.H. (2003). Some nutritional, pomological and physical properties of cornelian cherry (Cornus mas L.). Journal of Food Engineering, 60, 335-341.

Demir, F., Özcan, M. (2001). Chemical and technological properties of rose (Rosa canina L.) fruits grown wild in Turkey. Journal of Food Engineering, 47(4), 333-336.

Dogan, A., Kazankaya, A. (2006). Fruit properties of rose hip species grown in Lake Van Basin (Eastern Anatolia Region). Asian Journal of Plant Sciences, 5(1), 120-122.

Ekincialp, A., Kazankaya, A. (2012). Determination of some physical and chemical properties in rosehip (Rosa spp.) genotypes in Hakkari region. Yüzüncü Yil Üniversitesi Journal of Agricultural Sciences, 22(1), 7-11. 
Ercişli, S. (2007). Chemical composition of fruits in some rose (Rosa spp.) species. Food Chemistry, 104, 1379-1384.

Ercişli, S., Eşitken, A. (2004). Fruit characteristics of native rose hip (Rosa spp.) selections from the Erzurum province of Turkey. New Zealand Journal of Crop and Horticultural Science, 32, 51-53.

Ersoy, N., Özen, M.S. (2016). Some physico-chemical characteristics in fruits of rose hip (Rosa spp.) genotypes from Bolu province in western part of Turkey. Agroknowledge Journal, 17(2), 191-201.

Ghiorghiță, G., Maftei, D.E., Nicuta, D., Rati, I.V. (2012a). Study of several parameters in Rosa canina L. genotypes from native habitats in Romania and the in vitro response of this species. Academy of Romanian Scientists, Annals Series on Biological Sciences, 1(1), 91-109. Online Edition ISSN 2285-4177.

Ghiorghiță, G., Antohe, N., Rați, I.V., Maftei, D.E. (2012b). The study of some parameters of Rosa canina L. genotypes from different native populations and from the same population. Analele Stiiințifice ale Universităţii „Al. I. Cuza” Iaşi s. II a. Biologie vegetală, 58(1), 19-27.

Godwin, H. (1975). The history of the British flora, a factual basis for phytogeography. Second Edition. Cambridge University press, New York.

Gudin, S. (2000). Rose: genetics and breeding. Plant Breeding Reviews, 17, 159-189.

Güneș, M. (2010). Pomological and phenological characteristics of promising rose hip (Rosa) genotypes. African Journal of Biotechnology, 9(38), 6301-6306.

Güneș, M., Dölek, Ü., Elmastaș, M. (2016). Pomological changes in some rosehip species during ripening. Journal of Agricultural Faculty of Gaziosmanpasa University, 33(3), 214-222.

Hrotkó, K., Magyar, L., Gyeviki, M. (2008). Evaluation of native hybrids of Prunus fruticosa. Acta Agriculturae Serbica, 13(25), 41-45.

Jain, R.K., Bal, S. (1997). Physical properties of pearl millet. Journal of Agricultural Engineering Research, 66, 85-91.

Jian, H., Zhang, H., Tang, K., Li, S., Wang, Q., Zhang, T., Qiu, X., Yan, H. (2010). Decaploidy in Rosa praelucens Byhouwer (Rosaceae) endemic to Zhongdian plateau, Yunnan, China. Caryologia, 63(2), 162-167.

Kovács, S., Tóth, M.G., Facsar, G. (2000). Fruit quality of some rose species native in Hungary. Acta Horticulturae, 538, 103-109.

Mármol, I., Sánchez-de-Diego, C., Jiménez-Moreno, N., AncínAzpilicueta, C., Rodríguez-Yoldi, M.J. (2017). Therapeutic applications of rose hips from different Rosa species. International Journal of Molecular Science, 18, 1-37.

McCabe, W.L., Smith, J.C., Harriott, P. (1986). Unit operations of chemical engineering. Mc Graw-Hill, New York.

Nikolić, T. ed. (2018). Flora Croatica baza podataka. On-Line (http://hirc.botanic.hr/fcd). Botanički zavod, Prirodoslovno-matematički fakultet, Sveučilište u Zagrebu.
Popek, R. (1996). Biosystematyczne studia nad rodzajem Rosa L. w Polsce i krajach ościennych. Wydawnictwo naukowe WSP, Kraków.

Rehder A. (1940). Manual of cultivated trees and shrubs. The MacMillan Company, New York.

Rosu, C.M., Manzu, C., Olteanu, Z., Oprica, L., Oprea, A., Ciornea, E., Zamfirache, M.M. (2011). Several fruit characteristics of Rosa sp. genotypes from the northeastern region of Romania. Not Bot Horti Agrobo, 39(2), 203-208.

Smulders, M.J.M., Arens, P., Koning-Boucoiran, C.F.S., Gitonga, V.W., Krens ,F.A., Atanassov, A., Atanassov, I., Rusanov, K.E., Bendahmane, M., Dubois, A., Raymond, O., Caissard, J.C., Baudino, S., Crespel, L., Gudin, S., Ricci, S.C., Kovatcheva, N., Van Huylenbroeck, J., Leus, L., Wissemann, V., Zimmermann, H., Hensen, I., Werlemark, G., Nybom, H. (2011). Rosa. In Kole C. (eds), Wild crop relatives: genomic and breeding resources plantation and ornamental crops, Springer-Verlag, Berlin Heidelberg, 243-275 pp.

Soare, R., Bonea, D., Iancu, P., Niculescu, M. (2015). Biochemical and technological properties of Rosa canina L. fruits from spontaneous flora of Oltenia, Romania. Bulletin UASVM Horticulture, 72(1), 182-186.

Šindrak, Z., Jemrić, T., Baričević, L., Han Dovedan, I., Fruk, G. (2012). Fruit quality of dog rose seedlings (Rosa canina L). Journal of Central European Agriculture, 13(2), 321330.

Tomljenović, N. (2019). Morfološka, pomološka i genetska varijabilnost genotipova divlje ruže (Rosa canina L.). Doctoral thesis, University of Zagreb Faculty of Agriculture, Zagreb, Croatia, 159-169 pp.

Türkben, C., Barat, E., Çopur, Ö.U., Durgut, E., Himelrick, D.G. (2005). Evaluation of rose hips (Rosa spp.) selections. International Journal of Fruit Science, 5(2), 113-121.

Uggla, M., Gao, X., Werlemark, G. (2003). Variation among and within dog rose taxa (Rosa sect. Caninae) in fruit weight, percentages of fruit flesh and dry matter, and vitamin $C$ content. Acta Agriculturae Scandinavica, Section B - Soil \& Plant Science, 53(3), 147-155.

Vasić, D., Paunović, D., Špirović-Trifunović, B., Miladinović, J., Vujošević, L., Đinović, D., Popović-Đorđević, J. (2020). Fatty acid composition of rosehip seed oil. Acta Agriculturae Serbica, 25(49), 45-49.

Werlemark, G. (2000). Genetic variability and reproductive strategies in Nordic dogroses, Rosa section Caninae. Doctoral thesis, Swedish University of Agricultural Sciences, Alnarp, Sweden.

Werlemark, G., Nybom, H. (2010). Dogroses: botany, horticulture, genetics and breeding. In: Janick J. (eds), Horticultural Reviews, 36, 199-255.

Wissemann, V. (2003). Classification | Conventional taxonomy of wild roses. In: Roberts A., Debener T., Gudin S. (eds), Encyclopedia of rose science, Academic Press, London, 111-117 pp.

Wrońska-Pilarek, D., Jagodziński, A.M. (2009). Pollen morphological variability of Polish native species of Rosa L. (Rosaceae). Dendrobiology, 62, 71-82. 
